\title{
Implications of the Presence of Maturing Fruit on Carbohydrate and Nitrogen Distribution in Grapevines under Postveraison Water Constraints
}

\author{
Gerhard C. Rossouw ${ }^{3}$ \\ National Wine and Grape Industry Centre, School of Agricultural and Wine Sciences, Charles Sturt \\ University, Wagga Wagga, New South Wales 2678, Australia
}

Jason P. Smith ${ }^{1}$

National Wine and Grape Industry Centre, Charles Sturt University, Wagga Wagga, New South Wales 2678, Australia

\section{Celia Barril}

National Wine and Grape Industry Centre, School of Agricultural and Wine Sciences, Charles Sturt University, Wagga Wagga, New South Wales 2678, Australia

\author{
Alain Deloire ${ }^{2}$ \\ National Wine and Grape Industry Centre, Charles Sturt University, Wagga Wagga, New South Wales \\ 2678, Australia

\begin{abstract}
Bruno P. Holzapfel
National Wine and Grape Industry Centre, New South Wales Department of Primary Industries, Wagga Wagga, New South Wales 2678, Australia
\end{abstract}

\begin{abstract}
ADDITIONAL INDEX wORDS. starch mobilization, nitrogen allocation, amino acids, water deficit, sucrose translocation
Abstract. Grapevine (Vitis vinifera) berries are sugar and nitrogen $(\mathrm{N})$ sinks between veraison and fruit maturity. Limited photoassimilation, often caused by water constraints, induces reserve total nonstructural carbohydrate (TNC) remobilization, contributing to berry sugar accumulation, while fruit $\mathbf{N}$ accumulation can be affected by vine water supply. Although postveraison root carbohydrate remobilization toward the fruit has been identified through ${ }^{14} \mathrm{C}$ tracing studies, it is still unclear when this remobilization occurs during the two phases of berry sugar accumulation (rapid and slow). Similarly, although postveraison $N$ reserve mobilization toward the fruit has been reported, the impact of water constraints during berry $\mathbf{N}$ accumulation on its translocation from the different grapevine organs requires clarification. Potted grapevines were grown with or without fruit from the onset of veraison. Vines were irrigated to sustain water constraints, and fortnightly root, trunk, shoot, and leaf structural biomass, starch, soluble sugar, total $\mathrm{N}$, and amino $\mathrm{N}$ concentrations were determined. The fruit sugar and $\mathrm{N}$ accumulation was also assessed. Root starch depletion coincided with root sucrose and hexose accumulation during peak berry sugar accumulation. Defruiting at veraison resulted in continuous root growth, earlier starch storage, and root hexose accumulation. Leaf $\mathbf{N}$ depletion coincided with fruit $\mathbf{N}$ accumulation, while the roots of defruited vines accumulated $\mathbf{N}$ reserves. Root growth, starch, and $\mathbf{N}$ reserve accumulation were affected by maturing fruit during water constraints. Root starch is an alternative source to support fruit sugar accumulation, resulting in reserve starch depletion during rapid fruit sugar accumulation, while root starch refills during slow berry sugar accumulation. On the other hand, leaf $N$ is a source toward postveraison fruit $N$ accumulation, and the fruit $\mathrm{N}$ accumulation prevents root $\mathrm{N}$ storage.
\end{abstract}

Grapevine berries are sinks for the incorporation of both carbohydrates (Davies and Robinson, 1996) and N (RoubelakisAngelakis and Kliewer, 1992) between veraison and fruit maturity. Restricted TNC availability, induced by limited leaf photoassimilation, can cause starch redistribution from the roots during berry sugar accumulation (Candolfi-Vasconcelos et al., 1994), while $\mathrm{N}$ concentrations in the berries and roots are

Received for publication 23 Nov. 2016. Accepted for publication 9 Jan. 2017 This work was supported by the National Wine and Grape Industry Centre, and the Australian grapegrowers and winemakers through their investment body, Wine Australia, with matching funds from the Australian Government.

${ }^{1}$ Current address: Institut für Allgemeinen und ökologischen Weinbau, Hochschule Geisenheim University, Geisenheim, 65366, Germany

${ }^{2}$ Current address: Montpellier SupAgro, Montpellier, 34060, France

${ }^{3}$ Corresponding author. E-mail: grossouw@csu.edu.au. affected by abiotic conditions, such as vine water availability, during the growing season (Araujo et al., 1995). Furthermore, apart from also being affected by vine $\mathrm{N}$ supply, the $\mathrm{N}$ reserve accumulation in the roots is restricted by the presence of fruit before and after veraison (Rodriguez-Lovelle and Gaudillere, 2002). It is still unclear how the postveraison distribution of TNC and $\mathrm{N}$ reserves among the different organs, are affected by a combination of fruit presence and sustained water constraints. A further question remains on how this distribution contributes to, or inhibits, TNC and N reserve storage, or the contents of TNC and $\mathrm{N}$ in the fruit during berry maturation.

In plant roots, TNC are mainly stored as starch, which can be hydrolyzed, yielding osmotic active soluble sugars (Regier et al., 2009). Apart from the possible remobilization of sugars via phloem sucrose transportation (Ruan et al., 2010) between 
the perennial vine parts (the roots and trunk) and the ripening berries, thereby contributing to berry sugar accumulation (Candolfi-Vasconcelos et al., 1994), sugars also accumulate in various tissues of water stressed plants, to aid in osmotic regulation (Regier et al., 2009). Therefore, upon water constraints during berry sugar accumulation, the accumulation of soluble sugars in different vine parts could theoretically contribute to various functions; e.g., to facilitate TNC remobilization, and to improve abiotic stress tolerance. As grapevines are perennial plants, the storage of starch reserves at the end of the season is essential for reserve TNC utilization the following season, required for vegetative and reproductive development from budburst (Holzapfel et al., 2010). Depleted root starch concentration can then lead to limited initiation and development of the inflorescence, and decreased fruit set and fruit yield the following season (Smith and Holzapfel, 2009).

The $\mathrm{N}$ allocation to grapevine berries, and subsequent accumulation during berry maturation is, from a wine quality perspective, essential as it determines the juice yeast assimilable $\mathrm{N}$ content, influencing fermentation and wine composition. However, root $\mathrm{N}$ accumulation late in the growing season is important for its overwintering storage (Cheng et al., 2004). Similar to TNC, N reserves are used toward the initiation of early season vegetative growth, where their mobilization regulate spring growth and account for most of the $\mathrm{N}$ distribution until around flowering, as $\mathrm{N}$ soil uptake is usually still insufficient at this stage (Zapata et al., 2004). Nitrogen accumulation in the perennial vine parts usually initiates before berry maturity, and the reserves continue to increase until leaf fall (RoubelakisAngelakis and Kliewer, 1992). The presence of fruit reduces $\mathrm{N}$ assimilation in grapevine roots (Morinaga et al., 2003). Nitrogen is mostly stored in the roots, and these reserves consists of a range of amino acids and proteins (Zapata et al., 2004). Amino acids in plants are involved in the regulation of $\mathrm{N}$ metabolism, and play essential roles in $\mathrm{N}$ transport and storage (Roubelakis-Angelakis and Kliewer, 1992). The metabolic pathway related to the $\alpha$-ketoglutarate family of amino acids, yields glutamic acid, glutamine, arginine, and proline. These amino acids are abundant in plants, and have distinct roles in $\mathrm{N}$ metabolism (Verma et al., 1999). Glutamic acid is the intermediate product of nitrate and ammonium assimilation, and a precursor for the synthesis of glutamine, arginine, and proline (Berg et al., 2002). Arginine is considered the main N-storage amino acid in grapevines (Xia and Cheng, 2004), while glutamine is an essential $\mathrm{N}$ transporter (Coruzzi and Last, 2000). Proline accumulation is linked to osmotic adjustment following abiotic plant stresses (Hare and Cress, 1997). The metabolism of the $\alpha$-ketoglutarate-derived amino acids is therefore essential to regulate plant $\mathrm{N}$ partitioning and distribution, particularly during abiotic constraints.

The aim of this experiment was to determine the effect of fruit presence during sustained postveraison water constraints, on the TNC and $\mathrm{N}$ distribution within grapevines. The first goal was to investigate the response in the structural development of the leaves, shoots, trunk, and roots, based on the presence of fruit, during sustained water constraints. The second goal was to determine how fruit presence affects TNC accumulation in the different organs, during the sustained water constraints, and to assess which individual sugars accumulate in the grapevine roots during the two phases of berry maturation (rapid and slow sugar accumulation). The final goal was to determine how the presence of maturing fruit affects the allocation of $\mathrm{N}$ between the grapevine organs, and to identify potential contributions of amino $\mathrm{N}$, and especially the amino acids yielded from $\alpha$-ketoglutarate metabolism, toward $\mathrm{N}$ storage or translocation.

\section{Materials and Methods}

EXPERIMENTAL DESIGN. Own-rooted 'Shiraz' grapevines, grown in 50-L pots containing commercial potting mix, were used for this experiment in the 2014-15 growing season. The grapevines were grown in an outside bird-proof cage in the warm to very warm climate Riverina region of New South Wales, Australia. The 3-year-old grapevines were winter pruned to 10 spurs with two buds each, and arranged in four rows of nine vines each. From just after budburst, the grapevines were fertilized every 3 weeks with $250 \mathrm{~mL}$ of 50:1 diluted complete liquid fertilizer (MEGAMIX Plus; Rutec, Tamworth, Australia). In total, $\approx 2.6 \mathrm{~g} \mathrm{~N}$ was applied to each vine through fertilization, and the fertilization events were ceased 1 month before the start of the experiment, aiming to limit soil $\mathrm{N}$ uptake during the experiment. The grapevines were well watered between budburst and veraison, when irrigation was supplied three times a day to the point of visual free drainage from the pots.

Vines were shoot thinned so as to leave 17 shoots per vine from fruit set, and at the onset of veraison, $2 \mathrm{~d}$ after the first sign of berry softening was observed, the treatments were initiated. Four randomly selected vines, one from each row, were destructively harvested on the day when then the treatments were initiated, to represent the population of grapevines before the implementation of the treatments. After removal of the four initial vines, the eight remaining vines per row were evenly spaced out in the row. All bunches were removed on half the vines, to have 16 vines with, and 16 vines without fruit. Two vines in each row (one with fruit and one without fruit) were used as a visual reference to control irrigation scheduling, and received double the irrigation volume than the other vines. Irrigation was scheduled three times per day $(0800,1400$, and $1800 \mathrm{HR}$ ) for all vines, and the vines receiving double the irrigation, were rewatered each day just to the point of visual free drainage from the pots during the $1400 \mathrm{HR}$ irrigation event, through two irrigation emitters per pot. The remaining 24 vines were irrigated through one irrigation emitter, aiming to induce sustained water constraints. Selected vines were destructively harvested fortnightly from after the start of veraison, over four distinct harvest dates, as described later. Three vines with and without fruit each, and that received reduced irrigation, were harvested during each of these dates. Vines were distributed in triplicate for each treatment and harvest date. Pressurecompensated drip emitters $\left(4 \mathrm{~L} \cdot \mathrm{h}^{-1}\right.$ each) were used to supply the irrigation during the experiment, and the irrigation time ranged between 15 and $22 \mathrm{~min}$ per irrigation event (the same for each irrigation event per day) to reach free drainage from the pots receiving double irrigation, as described above. Before forecasted rainfall events, the top of the pots, around the trunks of the grapevines, were covered with plastic to avoid rain water from entering the soil.

At the destructive harvest dates; i.e., veraison [V (22 Dec. 2014)], V + 14 (5 Jan. 2015), V + 29 (20 Jan. 2014), V + 42 (2 Feb. 2015), and V +56 (16 Feb. 2014), the preselected grapevines were dismantled. Whole root systems, trunks, shoots, and leaves were separated, collected, and washed with phosphate-free detergent and rinsed with deionized water. Leaves were collected between 0800 and 1000 HR on each of 
the harvest dates. The fresh weights of these organs were determined, and the samples were oven-dried at $60{ }^{\circ} \mathrm{C}$ until constant dry weight. During the destructive harvests, root, trunk, shoot, leaf blade, and petiole subsamples were collected. The root subsamples consisted of full length roots taken within $10 \mathrm{~cm}$ from the basal part of the trunk, always between 2 and $6 \mathrm{~mm}$ in diameter, with at least $50 \mathrm{~g}$ in total fresh weight. Soil particles were shaken off and the roots rapidly rinsed with deionized water, before the samples being frozen in liquid $\mathrm{N}$. Trunk subsamples, $10 \mathrm{~cm}$ in length, were taken from $20 \mathrm{~cm}$ above soil level. One whole shoot per vine represented the shoot subsamples, whereas 20 leaves from the base of one shoot per vine represented the leaf blade and petiole subsamples. Berries (50 per vine) were also collected between 0800 and 1000 HR each day, and all subsamples were immediately frozen in liquid $\mathrm{N}$ and stored at $-80{ }^{\circ} \mathrm{C}$. Rainfall, atmospheric temperature, and relative humidity were recorded and collected from an on-site weather station, and the vapor pressure deficit was calculated (Castellví et al., 1996).

WATER STATUS AND Leaf Gas EXChange. Measurements of stem water potential (SWP) were conducted weekly according to Choné et al. (2001), selecting one healthy leaf from each vine on a main shoot and enclosing it with aluminum foil bags for $30 \mathrm{~min}$ between 1200 and $1400 \mathrm{HR}$. The leaves were then placed in a pressure chamber to measure SWP (model 1000; PMS instruments, Albany, OR). A portable photosynthesis system instrument (LCA-4; ADC Bioscientific, Hoddesdon, UK) was used to measure leaf surface temperature, stomatal conductance $\left(g_{\mathrm{S}}\right)$, and photosynthesis $\left(\mathrm{P}_{\mathrm{n}}\right)$. Two healthy, fully intact leaves were chosen weekly on each vine between the fourth and seventh shoot node position, to be used for these measurements between 1200 and 1400 HR on clear, noncloudy days.

VEGETATIVE AND REPRODUCTIVE DEVELOPMENT. The total fruit fresh weight of each grapevine was recorded at each destructive harvest. Subsamples of 50 berries per vine were used to determine the fresh weight per berry, and were juiced to measure the juice total soluble solid (TSS) concentration with a digital bench refractometer (PR-101; Atago, Tokyo, Japan). Berry soluble solid content (SSC) was calculated on the basis of berry fresh weight and TSS concentration.

The total tissue dry weight of whole root systems, trunks, shoots, and leaves and petioles were calculated for each vine, by combining the weights measured from the dried samples and the estimated dry weights of the subsamples. The subsample dry weights were estimated through the percentage weight loss during drying of the main samples. The structural biomass of these tissues was determined by subtracting the TNC content from the total biomass. Ground berry powder $(5 \mathrm{~g})$ from each vine was freeze-dried (Gamma 1-16 LSC; Christ, Osterode am Harz, Germany), and the berry dry weight estimated from the weight loss during drying.

TNC. Whole, dried plant parts, collected during the destructive harvest dates (roots, trunks, shoots, and combined leaf petioles and blades), were ground through a heavy duty cutting mill (SM2000; Retsch, Haan, Germany) to $5 \mathrm{~mm}$ and a subsample was then ground to $0.12 \mathrm{~mm}$ by using a ultracentrifugal mill (ZM200; Retsch). Starch (in the roots, trunks, shoots, and leaves), and total sugar (in the trunk, shoots, and leaves) concentrations in a $20 \mathrm{mg}$ subsample were determined following the methods outlined in Smith and Holzapfel (2009).

The concentrations of sucrose, glucose, and fructose in the ground root tissue were measured from a $200 \mathrm{mg}$ subsample, as modified from Reed et al. (2004), and used to calculate the root total sugar concentrations. Extractions were conducted, once in $2 \mathrm{~mL}$ of a $200 \mathrm{mg} \cdot \mathrm{L}^{-1}$ mannitol (internal standard) solution, followed by two more extractions in $2 \mathrm{~mL}$ ultrapure water. Extract solutions were homogenized with the root tissue, before incubation in an $80^{\circ} \mathrm{C}$ water bath for $15 \mathrm{~min}$, before being centrifuged at $3000 g_{\mathrm{n}}$ for $5 \mathrm{~min}$. The three supernatants were collected together, and purified through a solid-phase extraction cartridge, containing reverse phase $\mathrm{C}_{18}$ packing. The cartridges were first preequilibrated with $4 \mathrm{~mL}$ methanol followed by $8 \mathrm{~mL}$ ultrapure water, and the sample was finally eluted with $1.5 \mathrm{~mL}$ ultrapure water. A centrifugal evaporator (CentriVap 7812014; Labconco, Kansas City, MO) was used to evaporate the purified supernatants to dryness, before being resuspended in $1 \mathrm{~mL}$ ultrapure water. The suspensions were placed in an ultrasonic waterbath (FX14; Unisonics, Sydney, Australia) for $30 \mathrm{~min}$, and filtered through a $0.2-\mu \mathrm{m}$ cellulose acetate syringe filter. Final samples of $60 \mu \mathrm{L}$ were injected into a high-performance liquid chromatography (HPLC) system (600 series; Waters, Milford, MA), with ultrapure water used as mobile phase, pumped at a flow rate of 0.4 $\mathrm{mL} \cdot \mathrm{min}^{-1}$. Sugars in the samples were separated with a monosaccharide column $\left[300 \times 7.8 \mathrm{~mm}, 8 \mu \mathrm{m}\left(\right.\right.$ REZEX $8 \% \mathrm{~Pb}^{2+}$; Phenomenex, Torrance, CA)]. The column was heated to $75^{\circ} \mathrm{C}$, and sugars were detected with a refractive index detector (model 2414; Waters). Standard solutions of sucrose, glucose, fructose, and mannitol were used to determine the retention times and to establish calibration curves.

Total N Concentration. $\mathrm{N}$ concentrations were determined in the finely ground, dried samples of roots, trunks, shoots, and combined leaf blades and petioles. For the fruit, 50 frozen berries were ground to a fine powder under liquid $\mathrm{N}$ with an analytical mill (A11; IKA, Selangor, Malaysia), freeze-dried (Gamma 1-16 LSC), and used for the determination of fruit $\mathrm{N}$ concentration. $\mathrm{N}$ concentration in $200 \mathrm{mg}$ of a representative sample were determined by the LECO method (Standard methods of Rayment and Lyons, Soil chemical methods, Australasia, Dumas Combustion Method 6B2b), using an elemental analyzer (CNS TruMAC; LECO Corp., St. Joseph, MI).

Amino N concentration. Subsamples of the fruit, roots, trunks, shoots, leaf blades, and petioles were taken from $-80{ }^{\circ} \mathrm{C}$ storage and ground to a powder under liquid $\mathrm{N}$, using an analytical mill (A11; IKA). Free amino acids were extracted from a $100 \mathrm{mg}$ subsample of the ground tissue, using $100 \mu \mathrm{L}$ of an $80 \%(\mathrm{v} / \mathrm{v})$ methanol solution. The samples were vortexed for $1 \mathrm{~min}$, and sonicated for $15 \mathrm{~min}$ at room temperature, before centrifugation at $12,000 \mathrm{~g}_{\mathrm{n}}$ for $10 \mathrm{~min}$. The supernatant $(20 \mu \mathrm{L})$ was mixed with $475 \mu \mathrm{L} 0.25 \mathrm{M}$ borate buffer ( $\mathrm{pH} 8.5)$ and $5 \mu \mathrm{L}$ internal standard $(10 \mathrm{~mm} \mathrm{~L}$ hydroxyproline), and $100 \mu \mathrm{L}$ of the mixture used in the derivatization of the amino groups, according to Haynes et al. (1991), using 9-fluoreonylethyl chloroformate. Amino acids were analyzed by a HPLC system (600 series; Waters), and were separated with a $\mathrm{C}_{18}$ column $[4.6 \times 150 \mathrm{~mm}, 5 \mu \mathrm{m}$ (Zorbax Eclipse plus; Agilent, Santa Clara, CA)], and quantified with a fluorescence detector (model 2475; Waters) according to Haynes et al. (1991). The $\mathrm{N}$ concentration of free amino acids was determined in relation to the amino $\mathrm{N}$ atoms of each amino acid. Total free amino $\mathrm{N}$ concentrations were determined from the amino $\mathrm{N}$ atoms of 17 free amino acids.

Statistical analysis. Data were analyzed using Statistica 12 (Statsoft, Tulsa, OK), with the analysis of variance used to 
test the significance of each variable. Fisher's least significant difference test was used to identify significant differences between means $(P<0.05)$.

\section{Results}

\section{Atmospheric conditions, leaf gas exchange, and SWP}

The average daily temperature and VPD data collected during each interval of the experiment are shown in Table 1.

The leaf surface temperatures were significantly the lowest during Interval 3, and significantly higher for the defruited vines during Interval 4 (Table 2). Fruit absence or presence did not induce significant differences in leaf $g_{\mathrm{S}}$ and $\mathrm{P}_{\mathrm{n}}$ at any stage of the experiment (Table 2). Stomatal conductance and $P_{n}$, however, reduced significantly between Intervals 1 and 2, and $g_{\mathrm{S}}$ of the fruited vines reduced further between Intervals 2 and 4. The fruited vines had significantly more negative SWP values than the defruited vines, albeit receiving the same amount of irrigation water. The SWP values generally became more negative as the experiment progressed, and were significantly more negative than during Interval 1 by Interval 2 for the fruited vines, and by Interval 3 for the defruited vines. Defruited vine SWP values also reduced significantly between Intervals 3 and 4.

\section{Dry weight, TNC, and $\mathrm{N}$ accumulation}

The fruit SSC per vine increased significantly during Intervals 1 and 2 (Table 3 ) at rates of 9.2 and $9.7 \mathrm{~g} \cdot \mathrm{d}^{-1}$ respectively, and rapid berry sugar accumulation therefore took place between $\mathrm{V}$ and $\mathrm{V}+29$. The fruit SSC accumulation per vine slowed down during Interval $3(P>0.05)$ at a rate of $7 \mathrm{~g} \cdot \mathrm{d}^{-1}$, and no accumulation took place during Interval 4 . The fruit $\mathrm{N}$ content per vine increased significantly during Interval 1 , and between $\mathrm{V}+14$ and $\mathrm{V}+42$ (Table 3 ) at rates of 111 and 32 $\mathrm{mg} \cdot \mathrm{d}^{-1}$, respectively. The fruit dry weight per vine increased significantly between $\mathrm{V}$ and $\mathrm{V}+29$ (Table 3). The fresh weight per berry increased significantly between $\mathrm{V}$ and $\mathrm{V}+29$, and then decreased during Interval 4 (Table 3).

Combined roots, trunk, shoots, and leaves per vine exhibited a significant increase in the TNC content of both treatments during Interval 4 (Table 3 ). These TNC contents also increased significantly in the defruited vines during Interval 3. Furthermore, the defruited vines had higher TNC content than the fruited vines as showed by the treatment main effect. Root TNC content accounted for most (53\% on average) of the total vine (excluding the fruit) TNC content (Table 3), and decreased significantly between $\mathrm{V}$ and $\mathrm{V}+29$ in the fruited vines, before increasing to the initial level by $\mathrm{V}+56$. The root $\mathrm{TNC}$ content in the defruited vines increased significantly between $\mathrm{V}+14$

Table 1. Summary of the periodic atmospheric temperature, vapor pressure deficit (VPD) and the total irrigation volume applied per grapevine during the different experimental intervals. Intervals $1,2,3$, or 4 refer to the periods of $\mathrm{V}$ (veraison) to $\mathrm{V}+14(14 \mathrm{~d}$ after veraison), $\mathrm{V}+14$ to $\mathrm{V}+29$ (29 d after veraison), $\mathrm{V}+29$ to $\mathrm{V}+42$ (42 d after veraison), or $\mathrm{V}+42$ to $\mathrm{V}+56$ (56 d after veraison), respectively.

\begin{tabular}{|c|c|c|c|c|c|}
\hline & \multirow[b]{2}{*}{ Treatment } & \multicolumn{4}{|c|}{ Time after veraison $(\mathrm{d})$} \\
\hline & & $\begin{array}{l}\mathrm{V} \text { to } \mathrm{V}+14 \\
\text { (Interval } 1 \text { ) }\end{array}$ & $\begin{array}{c}\mathrm{V}+14 \text { to } \mathrm{V}+29 \\
\text { (Interval 2) }\end{array}$ & $\begin{array}{c}\mathrm{V}+29 \text { to } \mathrm{V}+42 \\
\quad(\text { Interval } 3)\end{array}$ & $\begin{array}{c}\mathrm{V}+42 \text { to } \mathrm{V}+56 \\
\quad(\text { Interval } 4)\end{array}$ \\
\hline \multirow[t]{2}{*}{ Atmospheric temp $\left({ }^{\circ} \mathrm{C}\right)$} & Daily mean & 25.4 & 24.1 & 23.7 & 26.2 \\
\hline & Mean maximum & 33.3 & 31.6 & 31.0 & 34.4 \\
\hline \multirow[t]{2}{*}{ VPD $(\mathrm{kPa})$} & Daily mean & 2.3 & 1.6 & 1.7 & 2.2 \\
\hline & Mean minimum & 0.8 & 0.5 & 0.6 & 0.7 \\
\hline Irrigation (L/vine) & Periodic total & 50.4 & 54 & 46.8 & 50.4 \\
\hline
\end{tabular}

Table 2. The influence of grapevine fruiting during sustained water constraints on leaf surface temperature, stomatal conductance $\left(g_{\mathrm{S}}\right)$, net photosynthetic rate $\left(\mathrm{P}_{\mathrm{n}}\right)$, and stem water potential (SWP) averaged during the different experimental intervals. Intervals $1,2,3$, or 4 refer to the periods of V (veraison) to $\mathrm{V}+14(14 \mathrm{~d}$ after $\mathrm{V}), \mathrm{V}+14$ to $\mathrm{V}+29(29 \mathrm{~d}$ after $\mathrm{V}), \mathrm{V}+29$ to $\mathrm{V}+42(42 \mathrm{~d}$ after $\mathrm{V})$, or $\mathrm{V}+42$ to $\mathrm{V}+56(56 \mathrm{~d}$ after $\mathrm{V})$, respectively. The main effect indicates the mean measured values between $\mathrm{V}+14$ and $\mathrm{V}+56$ for each treatment. The fruited treatment consisted of vines with their fruit intact between $\mathrm{V}$ and $\mathrm{V}+56$, whereas the defruited treatment consisted of vines without fruit during the same period.

\begin{tabular}{|c|c|c|c|c|c|c|}
\hline & \multirow[b]{2}{*}{ Treatment } & \multicolumn{4}{|c|}{ Time after veraison (d) } & \multirow[b]{2}{*}{ Main effect } \\
\hline & & $\begin{array}{l}\mathrm{V} \text { to } \mathrm{V}+14 \\
\text { (Interval } 1 \text { ) }\end{array}$ & $\begin{array}{c}\mathrm{V}+14 \text { to } \mathrm{V}+29 \\
\quad(\text { Interval } 2)\end{array}$ & $\begin{array}{c}\mathrm{V}+29 \text { to } \mathrm{V}+42 \\
\quad \text { (Interval 3) }\end{array}$ & $\begin{array}{c}\mathrm{V}+42 \text { to } \mathrm{V}+56 \\
\quad \text { (Interval } 4)\end{array}$ & \\
\hline Leaf surface temp $\left({ }^{\circ} \mathrm{C}\right)$ & Fruited & $33.6 \mathrm{a}$ & $33.8 \mathrm{a}$ & $30.2 \mathrm{~b}$ & $* 33.3 \mathrm{a}$ & 33.0 \\
\hline \multirow[t]{2}{*}{$g_{\mathrm{S}}\left(\mathrm{mmol} \cdot \mathrm{m}^{-2} \cdot \mathrm{s}^{-1}\right)$} & Fruited & $27.7 \mathrm{a}$ & $8.9 \mathrm{~b}$ & $7.1 \mathrm{~b}$ & $5.8 \mathrm{~b}$ & 7.5 \\
\hline & Defruited & $29.3 \mathrm{a}$ & $12.2 \mathrm{~b}$ & $6.3 \mathrm{bc}$ & $1.7 \mathrm{c}$ & 8.8 \\
\hline $\mathrm{P}_{\mathrm{n}}\left(\mu \mathrm{mol} \cdot \mathrm{m}^{-2} \cdot \mathrm{s}^{-1}\right)$ & Fruited & $4.71 \mathrm{a}$ & $3.01 \mathrm{~b}$ & $3.80 \mathrm{ab}$ & $4.19 \mathrm{ab}$ & 3.71 \\
\hline \multirow[t]{2}{*}{ SWP (-MPa) } & Fruited & $* \mathrm{z} 1.47 \mathrm{a}^{\mathrm{y}}$ & $* 1.71 \mathrm{~b}$ & $* 1.65 \mathrm{~b}$ & $1.68 \mathrm{~b}$ & $* 1.62$ \\
\hline & Defruited & $* 1.37 \mathrm{a}$ & $* 1.41 \mathrm{ab}$ & $* 1.48 \mathrm{~b}$ & $1.64 \mathrm{c}$ & $* 1.43$ \\
\hline
\end{tabular}

${ }^{\mathrm{z}}$ Means separated within columns using Fisher's least significant difference (LSD) test, significant differences between the treatments $(*)$ are indicated at $P<0.05$.

${ }^{\mathrm{y}}$ Means separated within rows using Fisher's LSD test, significant differences are indicated at $P<0.05$. Where the same lower case letter appears in a row, values do not differ significantly. 
Table 3. Influence of sustained grapevine water constraints on the fruit total soluble solid concentration (TSS), total soluble solid content (SSC), N content, total fruit dry weight (DW) per vine, fresh weight (FW) per berry and the impact of grapevine fruiting on the nonstructural carbohydrate (TNC) content, $\mathrm{N}$ content, and DW of vegetative annual and perennial tissues per vine at the different destructive harvests. Intervals 1, 2, 3, or 4 refer to the periods of $\mathrm{V}$ (veraison) to $\mathrm{V}+14(14 \mathrm{~d}$ after $\mathrm{V}), \mathrm{V}+14$ to $\mathrm{V}+29(29 \mathrm{~d}$ after $\mathrm{V}), \mathrm{V}+29$ to $\mathrm{V}+42(42 \mathrm{~d}$ after $\mathrm{V})$, or $\mathrm{V}+42$ to $\mathrm{V}+56$ ( $56 \mathrm{~d}$ after $\mathrm{V})$, respectively. The main effect indicates the mean measured values between $\mathrm{V}+14$ and $\mathrm{V}+56$ for each treatment. The fruited treatment consisted of vines with their fruit intact between $\mathrm{V}$ and $\mathrm{V}+56$, whereas the defruited treatment consisted of vines without fruit during the same period.

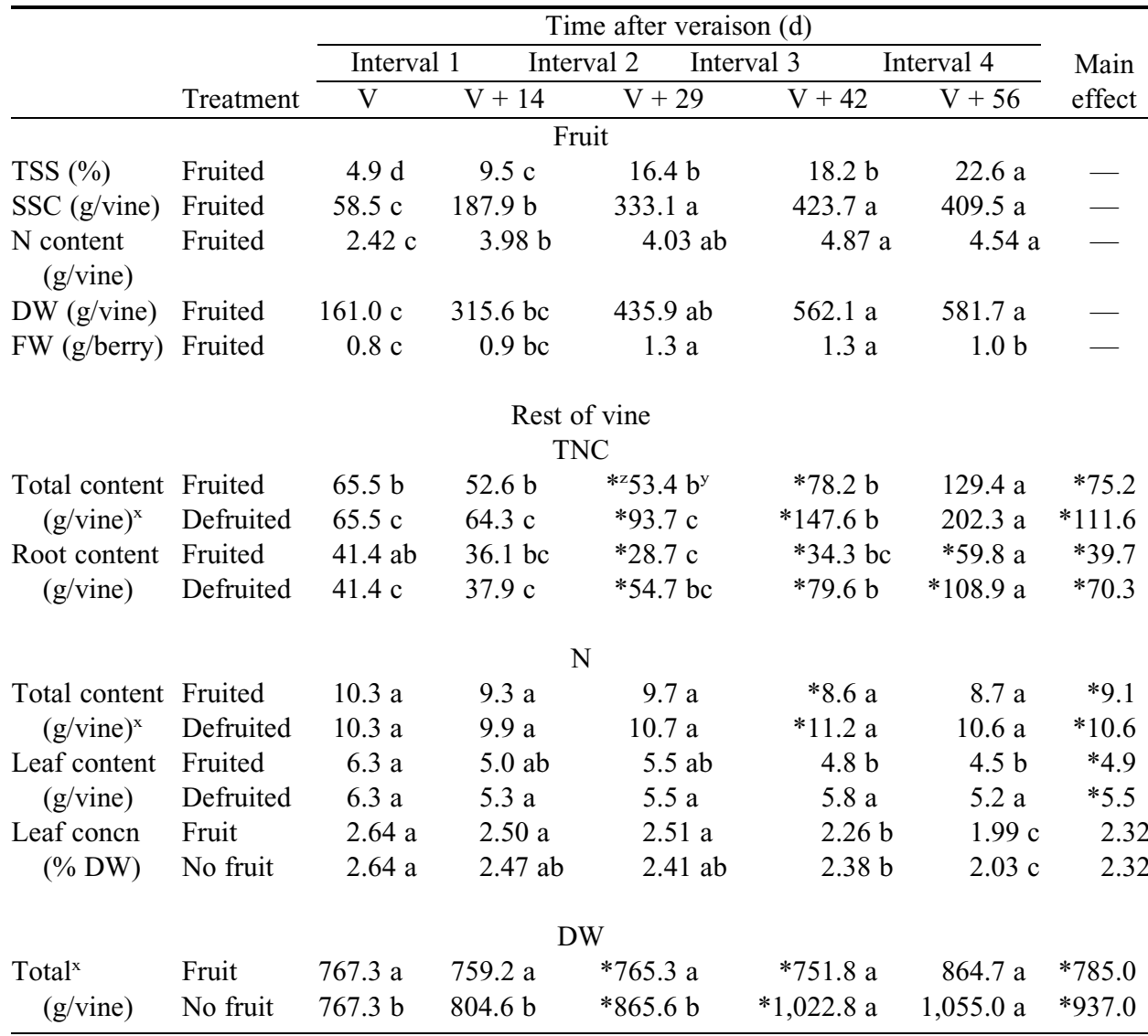

${ }^{\mathrm{z}}$ Means separated within columns using Fisher's least significant difference (LSD) test, significant differences between the treatments $(*)$ are indicated at $P<0.05$.

${ }^{\mathrm{y}}$ Means separated within rows using Fisher's LSD test, significant differences are indicated at $P<0.05$. Where the same lower case letter appears in a row, values do not differ significantly.

${ }^{\mathrm{x}}$ Indicate the combination of roots, trunks, shoots, and leaves per vine.

and $\mathrm{V}+42$, and also during Interval 4 . The root TNC content in defruited vines was significantly higher than that in the fruited vines from $\mathrm{V}+29$ onward.

The total $\mathrm{N}$ content in combined roots, trunks, shoots, and leaves per vine (vine $\mathrm{N}$ content) did not change significantly in vines of both treatments (Table 3 ). However, the defruited vines had significantly higher $\mathrm{N}$ content in combined roots, trunks, shoots, and leaves per vine, than the fruited vines as showed by the treatment main effect (Table 3 ). Most of the vine $\mathrm{N}$ content was present in the leaves ( $61 \%$ of total at veraison), and the leaf $\mathrm{N}$ content per vine in the fruited vines tended to decrease during Interval $1(P=0.07)$ (Table 3$)$. The leaf $\mathrm{N}$ content of those vines decreased significantly between $\mathrm{V}$ and $\mathrm{V}+42$, whereas that of the defruited vines did not change significantly. The defruited vines had significantly higher leaf $\mathrm{N}$ content per vine than the fruited vines as demonstrated by the treatment main effect.
Furthermore, the leaf $\mathrm{N}$ concentrations (Table 3 ) in vines of both treatments were, at veraison, within a range considered to indicate adequate vine $\mathrm{N}$ supply, and the $\mathrm{N}$ status of these vines could therefore be considered sufficient for 'Shiraz' vines after veraison (Holzapfel and Treeby, 2007). By estimation, and although not significantly affecting the total $\mathrm{N}$ content in a combination of the fruit, leaves, shoots, trunk, and roots per vine $(P>0.05)$, the fruited vines absorbed 0.6 and $0.4 \mathrm{~g}$ soil $\mathrm{N}$ per vine during respectively, Intervals 1 and 2. However, and while also not significantly contributing to the total vine $\mathrm{N}$ content $(P>$ $0.05)$, the defruited vines absorbed an estimated 0.8 and $0.5 \mathrm{~g} \mathrm{~N}$ per vine from the soil during Intervals 2 and 3 , respectively.

The total dry weight of combined roots, trunk, shoots, and leaves per vine did not change significantly in the fruited vines, whereas the defruited vines exhibited a significant increase during Interval 3 (Table 3). The defruited vines also had significantly higher dry weights per vine than the fruited vines, as a treatment main effect.

\section{Organ structural development}

The leaf and shoot structural dry weight per vine did not significantly differ among the treatments, and did not change significantly (Fig. 1A and B). There was no significant difference in trunk structural dry weight for both treatments, apart from the defruited vines exhibiting a larger trunk dry weight at $\mathrm{V}+42$ (Fig. 1C). The root structural dry weight did not significantly change in the fruited vines, whereas that of the defruited vines significantly increased from $\mathrm{V}+42$ (Fig. 1D).

\section{TNC}

StaRCh CONCENTRATION PER ORGAN. The leaf starch concentration was never significantly different between the treatments, and was similar to that at $\mathrm{V}$ until Interval 4 where it significantly increased (Fig. 2A). The shoot starch concentration in the both treatments increased significantly during Intervals 3 and 4 (Fig. 2B), and was significantly higher at $\mathrm{V}+56$ than at $\mathrm{V}$. The shoot starch concentration was significantly higher by $\mathrm{V}+42$ in the defruited vines.

The trunk starch concentration in the fruited vines was significantly higher at $\mathrm{V}$ than by $\mathrm{V}+42$, whereas that in the defruited vines was significantly higher by $\mathrm{V}+29$ (Fig. 2C). The root starch concentration in the fruited vines decreased 



Fig. 1. Effects of grapevine fruiting during sustained water constraints on the total (A) leaf (combination of leaf blades and petioles), (B) shoot, (C) trunk, and (D) root structural dry weight accumulation per vine. Time after veraison refers the different destructive harvest dates [ $\mathrm{V}$ (veraison), $\mathrm{V}+14$ (14 d after $\mathrm{V}), \mathrm{V}+29(29 \mathrm{~d}$ after $\mathrm{V}), \mathrm{V}+42(42 \mathrm{~d}$ after $\mathrm{V})$, and $\mathrm{V}+56(56 \mathrm{~d}$ after $\mathrm{V})]$. The fruited treatment consisted of vines with their fruit intact between $\mathrm{V}$ and $\mathrm{V}+$ 56 , whereas the defruited treatment consisted of vines without fruit during the same period $[$ mean $\pm \operatorname{SE}(\mathrm{n}=3)]$. significantly between $\mathrm{V}$ and $\mathrm{V}+29$, followed by a significant increase during Interval 4 back to the initial concentration (Fig. 2D). The root starch concentration in the defruited vines was significantly higher at $\mathrm{V}+56$ than at $\mathrm{V}$, and was significantly higher than that of the fruited vines at $V+29$.

\section{Total soluble sugar concentration per organ}

The leaf sugar concentration in the fruited vines significantly increased between $\mathrm{V}+14$ and $\mathrm{V}+42$, whereas that in the defruited vines significantly increased between $\mathrm{V}$ and $\mathrm{V}+$ 42 (Fig. 2E). The shoot sugar concentration in the defruited vines remained stable throughout the experiment (Fig. 2F). Although the shoot sugar concentration of the fruited vines significantly decreased during Interval 1 and then significantly increased until $\mathrm{V}+42$, the concentration at $\mathrm{V}+56$ was not different to that at $\mathrm{V}$.

The trunk sugar concentration significantly increased during Interval 2 and remained higher than at $\mathrm{V}$ until $\mathrm{V}+56$ in the fruited vines, whereas that in the defruited vines was significantly higher than at $\mathrm{V}$ at all stages (except $\mathrm{V}+29$ ) (Fig. 2G). The root total sugar concentration significantly decreased during Interval 1 , and then significantly increased during Interval 2 in the fruited vines (Fig. $2 \mathrm{H}$ ). At $\mathrm{V}+29$, the root sugar concentration in the fruited vines was significantly higher than at V. The fruited vine root sugar concentration then reduced significantly during Interval 4 . There were no significant changes in root sugar concentration in the defruited vines; however, the fruited vines had significantly higher root sugar concentration at $\mathrm{V}+29$ and $\mathrm{V}+42$, than the defruited vines.

\section{Individual root sugar concentrations}

The root sucrose concentration in the fruited vines significantly decreased during Interval 1 , and significantly increased during Interval 2 (Fig. 3A). By V + 42, these root sucrose concentrations were significantly higher than at $\mathrm{V}$, before decreasing to the concentration observed at $\mathrm{V}+14$ during Interval 4 . The root sucrose concentration in the defruited vines was significantly lower than at $\mathrm{V}$ by $\mathrm{V}+42$. The sucrose concentration of the roots was the same for the fruited and defruited vines except at $\mathrm{V}+29$ and $\mathrm{V}+42$, where it was significantly higher in the fruited vines.

Total hexose concentration; i.e., combined fructose and glucose concentrations, increased significantly during Interval 2 in the roots of the fruited vines (Fig. 3D). Glucose (Fig. 3C), and the total hexose concentrations, decreased significantly during Interval 4 in the roots. At V+56, both the total hexose and the fructose (Fig. 3B) concentrations in the roots of the fruited vines, were significantly higher than at $\mathrm{V}$. The root hexose concentration in the defruited vines increased gradually during the experiment, and from $\mathrm{V}+42$, both the total hexose and fructose concentrations were significantly higher than at $\mathrm{V}$. At $\mathrm{V}+42$, the fruited vines had significantly higher root hexose, fructose and glucose concentrations per vine, than those without fruit.

\section{Nitrogen}

TOtal N CONTENT PER ORgan. The development of total leaf $\mathrm{N}$ content per vine between $\mathrm{V}$ and $\mathrm{V}+56$ (Table 3) was described earlier. The shoot $\mathrm{N}$ content in vines of both treatments did not alter significantly (Fig. 4A), although the shoot $\mathrm{N}$ content in defruited vines was significantly higher than that in fruited vines, as determined by the treatment main effect. 

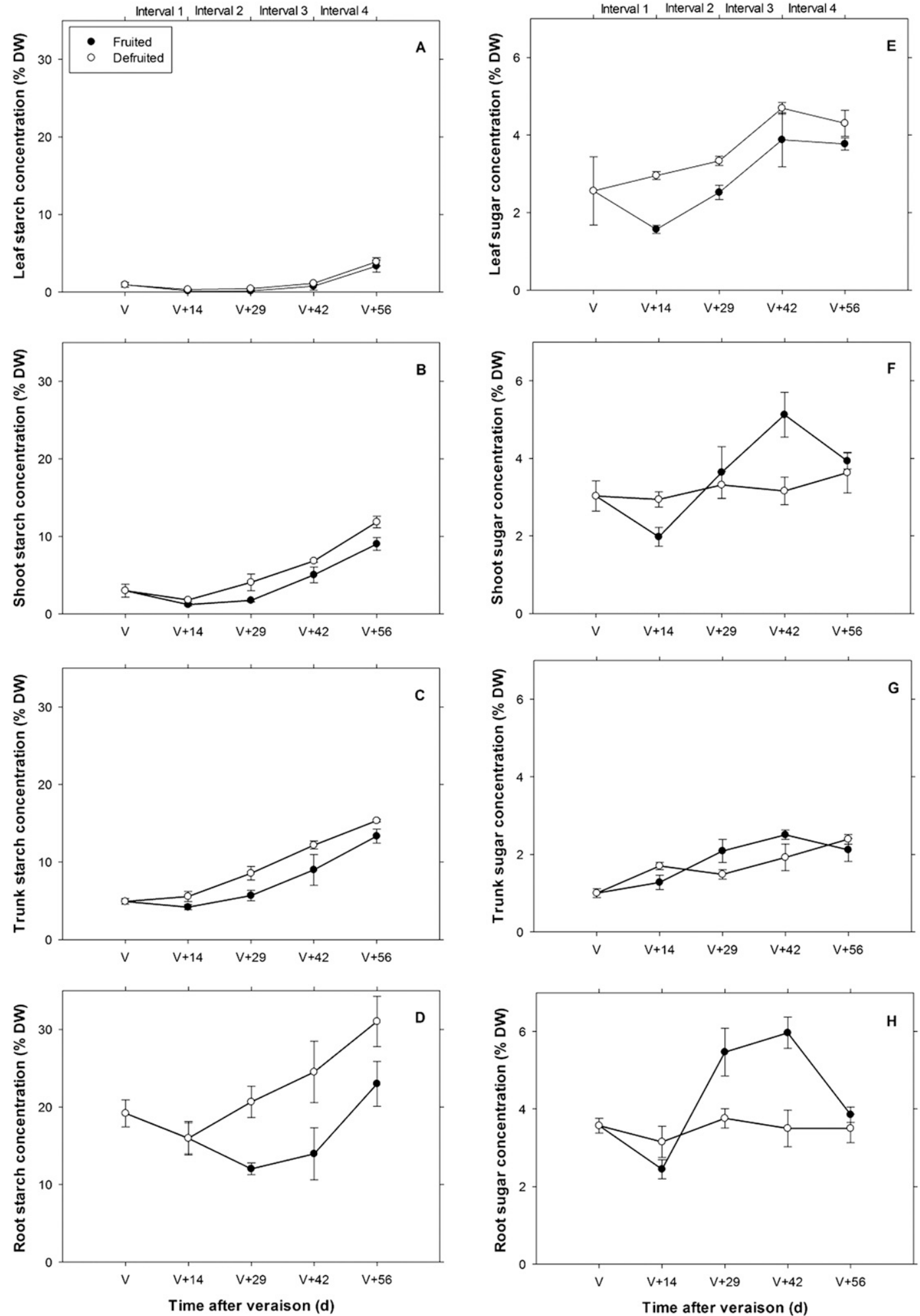

Fig. 2. Effects of grapevine fruiting during sustained water constraints on the leaf (combination of leaf blades and petioles), shoot, trunk, and root starch (A, B, C, and $\mathbf{D}$, respectively) and total sugar $(\mathbf{E}, \mathbf{F}, \mathbf{G}$, and $\mathbf{H}$, respectively) concentration dry weight) per vine. Time after veraison refers to the different destructive harvest dates [V (veraison), V + $14(14 \mathrm{~d}$ after V), V $+29(29 \mathrm{~d}$ after V), V + $42(42 \mathrm{~d}$ after V), and V $+56(56 \mathrm{~d}$ after $\mathrm{V})]$. The fruited treatment consisted of vines with their fruit intact between $\mathrm{V}$ and $\mathrm{V}+56$, whereas the defruited treatment consisted of vines without fruit during the same period [mean $\pm \operatorname{SE}(\mathrm{n}=3)]$.

The $\mathrm{N}$ content in vine trunks of both treatments increased significantly during Interval 1 . The trunk $\mathrm{N}$ content in the fruited vines was significantly higher at all the destructive harvests (except $\mathrm{V}+42$ ) than at $\mathrm{V}$ (Fig. 4B). In the defruited vines, the trunk $\mathrm{N}$ content was significantly higher during the rest of the experiment than at V. Furthermore, the defruited 

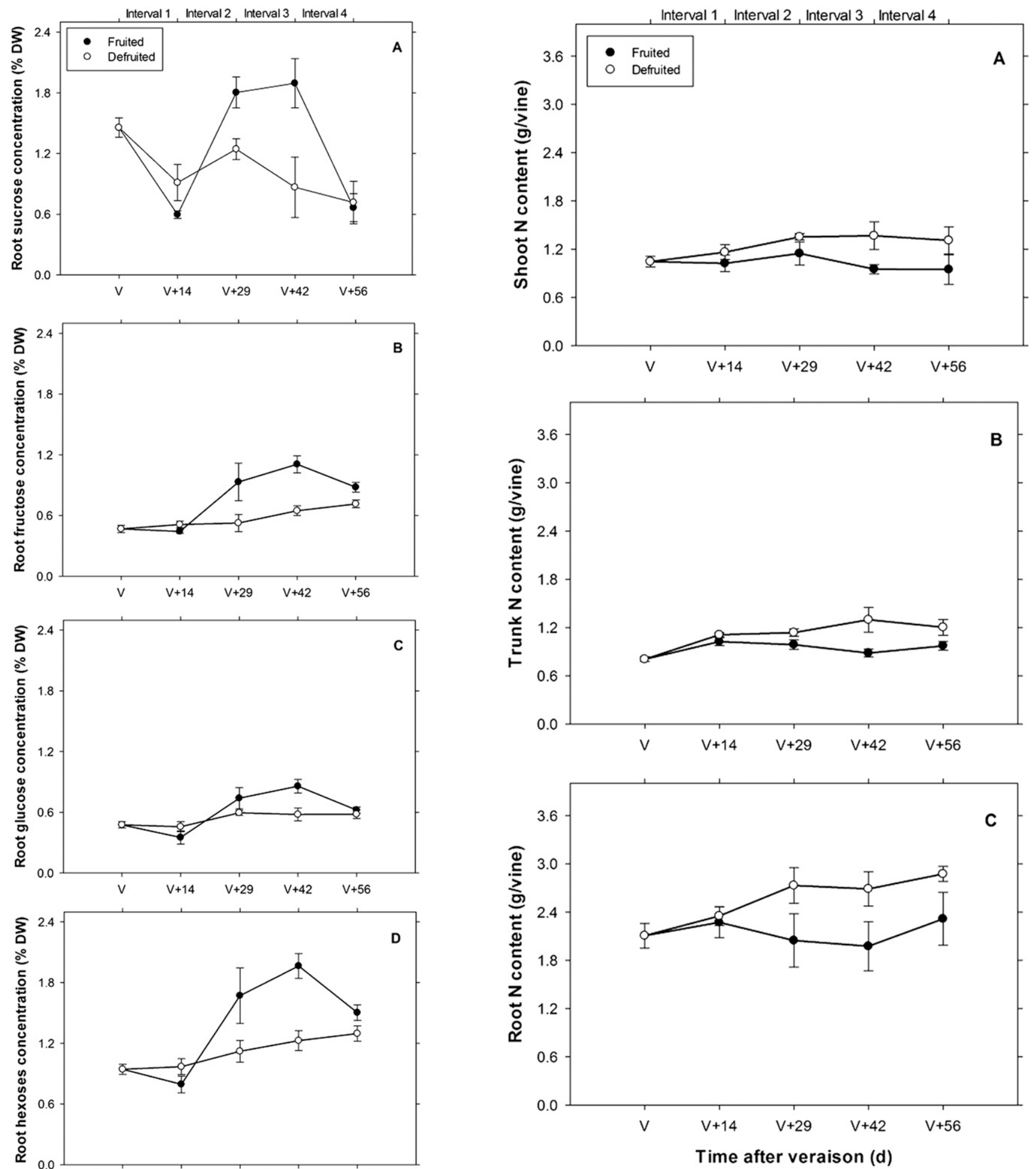

Fig. 4. Effects of grapevine fruiting during sustained water constraints on the nitrogen content per vine in the (A) shoots, $(\mathbf{B})$ trunks, and $(\mathbf{C})$ roots. Time after veraison refers to the different destructive harvest dates [V (veraison), $\mathrm{V}+14$ $(14 \mathrm{~d}$ after $\mathrm{V}), \mathrm{V}+29(29 \mathrm{~d}$ after $\mathrm{V}), \mathrm{V}+42(42 \mathrm{~d}$ after $\mathrm{V})$, and $\mathrm{V}+56(56 \mathrm{~d}$ after $\mathrm{V})$ ]. The fruited treatment consisted of vines with their fruit intact between $\mathrm{V}$ and $\mathrm{V}+56$, whereas the defruited treatment consisted of vines without fruit during the same period [mean $\pm \mathrm{SE}(\mathrm{n}=3)]$. destructive harvest dates [V (veraison), $\mathrm{V}+14(14 \mathrm{~d}$ after $\mathrm{V}), \mathrm{V}+29$ ( $29 \mathrm{~d}$ afte $\mathrm{V}), \mathrm{V}+42(42 \mathrm{~d}$ after $\mathrm{V})$, and $\mathrm{V}+56(56 \mathrm{~d}$ after $\mathrm{V})]$. The fruited treatment consisted of vines with their fruit intact between $\mathrm{V}$ and $\mathrm{V}+56$, whereas the defruited treatment consisted of vines without fruit during the same period $[$ mean $\pm \operatorname{SE}(\mathrm{n}=3)]$.

vines had significantly higher trunk $\mathrm{N}$ content than those with fruit, as determined by the treatment main effect. The root $\mathrm{N}$ content in the fruited vines did not change significantly 
(Fig. 4C); however, the root $\mathrm{N}$ content in the defruited vines was significantly higher than at $\mathrm{V}$ by $\mathrm{V}+29$. The defruited vines also had significantly higher root $\mathrm{N}$ content than those with fruit, as determined by the treatment main effect.

Total amino N CONCENTRATION PER ORGan. In the fruited vines, the fruit amino $\mathrm{N}$ concentration was significantly higher by $\mathrm{V}+29$ than at $\mathrm{V}$ (Fig. 5A). The fruit amino $\mathrm{N}$ concentration also increased significantly during Interval 4.

The leaf blade total amino $\mathrm{N}$ concentration in vines of both treatments increased significantly during Interval 1, but decreased significantly during Interval 2, and did not differ between the treatments (Fig. 5B). In the petioles of the fruited vines, the total amino $\mathrm{N}$ concentration increased significantly during Interval 1 (Fig. 5C), and was significantly higher than that in the defruited fruited vines at $\mathrm{V}+14$ and $\mathrm{V}+29$. Furthermore, during Interval 3, the petiole amino $\mathrm{N}$ concentration in the fruited vines decreased significantly. The total shoot amino $\mathrm{N}$ concentration increased significantly in the fruited vines during Interval 1 (Fig. 5D), and was significantly higher than that in the defruited vines at $\mathrm{V}+14$. The shoot amino $\mathrm{N}$ concentration of the fruited vines decreased significantly during Interval 2.

In the trunks of both treatments, the total amino $\mathrm{N}$ concentration increased significantly during Interval 1 (Fig. 5E). The trunk amino $\mathrm{N}$ concentration in the defruited vines was significantly lower than at $\mathrm{V}+14$ by $\mathrm{V}+42$, whereas that in the fruited vines
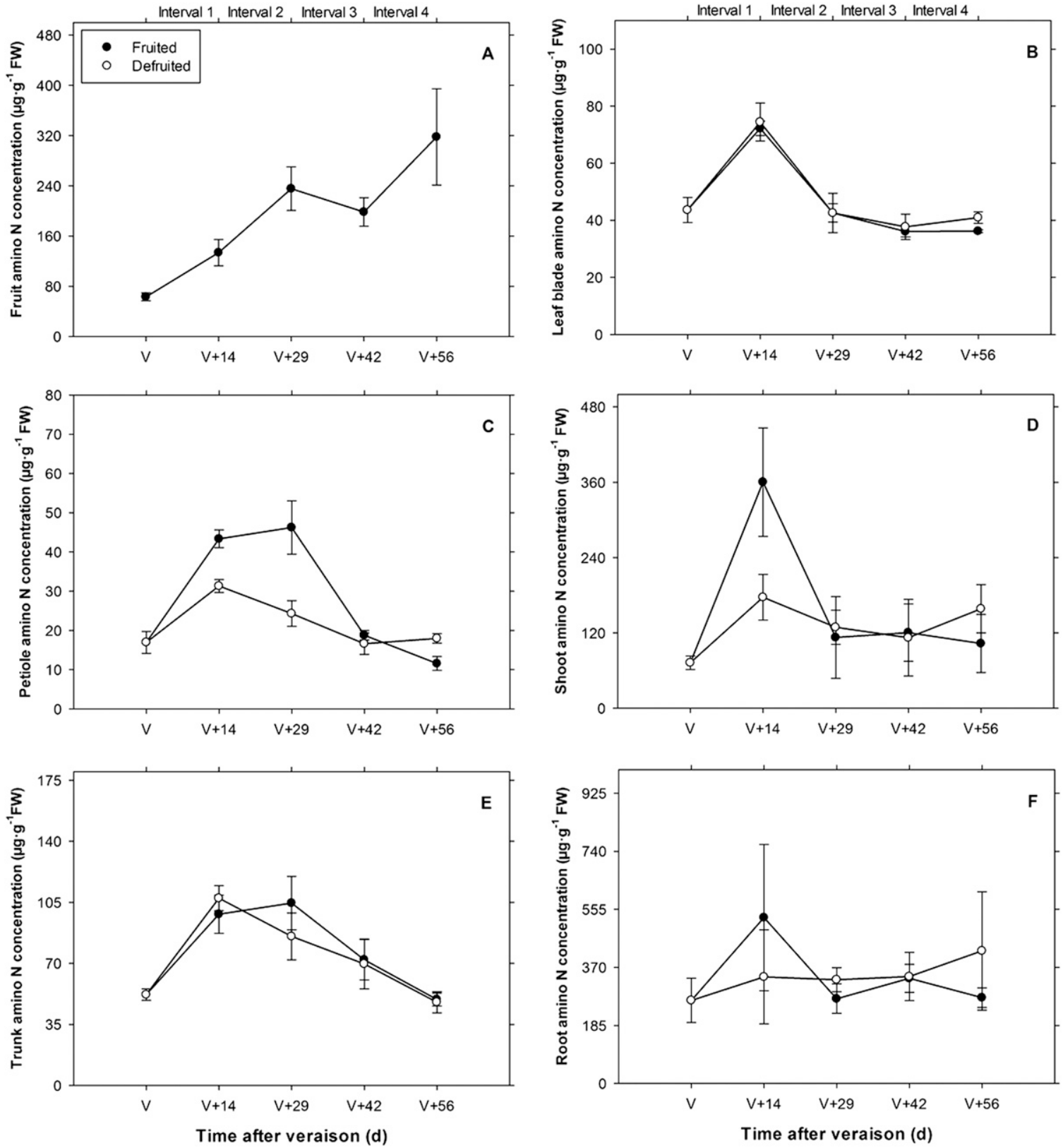

Fig. 5. Effects of grapevine fruiting during sustained water constraints on total amino nitrogen concentration fresh weight in the (A) fruit, (B) leaf blades, (C) leaf petioles, (D) shoots, $(\mathbf{E})$ trunks, and (F) roots. Time after veraison (d) refers to the different destructive harvest dates [V (veraison), V $+14(14 \mathrm{~d}$ after V), V +29 $(29 \mathrm{~d}$ after $\mathrm{V}), \mathrm{V}+42(42 \mathrm{~d}$ after $\mathrm{V})$, and $\mathrm{V}+56(56 \mathrm{~d}$ after $\mathrm{V})]$. The fruited treatment consisted of vines with their fruit intact between $\mathrm{V}$ and $\mathrm{V}+56$, whereas the defruited treatment consisted of vines without fruit during the same period [mean $\pm \operatorname{SE}(n=3)]$. 
decreased significantly during Interval 4 . In the roots, the total amino $\mathrm{N}$ concentration did not change significantly (Fig. 5F), and did not significantly differ between the treatments.

INDIVIDUAL AMINO ACID CONCENTRATIONS. The concentrations of arginine, glutamic acid, glutamine and proline, and amino acids derived from $\alpha$-ketoglutarate metabolism, are presented for the different organs in Fig. 6.

Arginine was the most abundant amino acid in the fruit, where its concentration increased significantly between $\mathrm{V}$ and $\mathrm{V}+29$. The fruited vines had higher leaf blade arginine concentration than the defruited vines at $\mathrm{V}+14$ and $\mathrm{V}+29$. Likewise, in the petioles, the arginine concentration in the fruited vines was significantly higher at $\mathrm{V}+14$ than that in the defruited vines. The shoot arginine concentration in the fruited vines increased significantly during Interval 1, and was significantly higher than that in the defruited vines at $\mathrm{V}+14$. In the defruited vines, the shoot arginine concentration was significantly higher at $\mathrm{V}+56$ than at $\mathrm{V}$. There were no significant differences in trunk and root arginine concentrations between the treatments, although between all of the perennial and vegetative annual organs, the roots had the highest arginine concentrations.

The fruit glutamic acid concentration was higher by $\mathrm{V}+42$ than at $\mathrm{V}$, whereas that in the leaf blades, petioles, and shoots never differed between the treatments. The glutamic acid concentration in leaf blades and petioles increased significantly during Interval 1 for both treatments. The trunk glutamic acid concentration in the defruited vines was significantly higher than that in the fruited vines at $\mathrm{V}+14$; however, it was significantly higher in the trunks of fruited vines at $\mathrm{V}+42$. There were no significant differences in root glutamic acid concentration.

The fruit glutamine concentration did not change significantly, whereas that in the leaf blades, petioles, shoot, and trunk increased significantly for both treatments during Interval 1. The glutamine concentration then decreased significantly in the leaf blades and shoots of the vines from both treatments during Interval 2, and also in the petioles and trunk in the defruited vines, whereas that in the petioles and trunk of the fruited vines decreased by $\mathrm{V}+42$. The glutamine concentration in the petioles of fruited vines was significantly higher than that of the defruited vines at $\mathrm{V}+29$, and at $\mathrm{V}+14$ in the shoots. The trunk and root glutamine concentrations never significantly differed between the treatments.

The fruit proline concentration increased significantly during Interval 4. There was no significant difference in the proline concentration between the treatments in the leaf blades (except at $\mathrm{V}+56$ where the defruited vines had higher concentration) and petioles, although these concentrations increased significantly during Interval 1, and also during Interval 4 in the leaf blades. Likewise, the proline concentration in both, shoots and trunks, did not differ significantly between the treatments, although it increased significantly during Interval 1 in the trunks, and then decreased during Interval 2 . The root proline concentration in the fruited vines increased significantly during Interval 1 before decreasing significantly during Interval 2, but was significantly higher in the roots of defruited vines at $\mathrm{V}+29$.

\section{Discussion}

Grapevines were grown with and without fruit between veraison and fruit maturity, and irrigation limited to create a sustained postveraison water constraint. The aim was to reduce leaf photoassimilation, and force greater reliance on stored carbohydrates for berry sugar accumulation in the fruiting vines. For the nonfruiting vines, the absence of the strong reproductive sink allowed vegetative growth and partitioning responses to water constraints to be examined in more detail. The TNC content in different organs, and the concentration changes of the major root sugars were investigated. The water constraints also aimed to alter the contribution of the different $\mathrm{N}$ sources toward fruit $\mathrm{N}$ accumulation, and the concentrations of amino $\mathrm{N}$ was determined in the different organs.

The more negative SWP values seen with the presence of fruit is not uncommon in deciduous fruit species. Berman and DeJong (1996), for example, described the higher crop load of peach (Prunus persica) trees under reduced irrigation to induce more negative SWP values. The crop load induced SWP differences in that study were attributed to either increased leaf transpiration of the higher cropping trees, or the reduced root growth of those trees and a subsequent inferior soil water uptake. In the present study, leaf $g_{\mathrm{S}}$ and $\mathrm{P}_{\mathrm{n}}$ were unaffected by fruit presence. However, if higher leaf transpiration rates of the fruited vines induced the more negative SWP values, it is probable that the leaf transpiration rate differences between the treatments occurred due to $g_{\mathrm{S}}$ variations during periods other than the middle of the day; e.g., midafternoon (Downton et al., 1987). The low midday $\mathrm{P}_{\mathrm{n}}$ values in the present study are, however, consistent with of the impact of the imposed grapevine water constraints on net photoassimilation (Medrano et al., 2003). In addition to the water constraints, and as illustrated in apple (Malus domestica) trees, the high midday leaf surface temperatures likely also contributed to the corresponding low $g_{S}$ values (Greer, 2015). Classification of the midday SWP values, according to published thresholds, confirms that water constraints were sustained from veraison to berry maturity (Van Leeuwen et al., 2009).

A depletion of root $\mathrm{TNC}$ coincided with rapid fruit sugar accumulation (Table 3 ), and root TNC reserves were seemingly not used toward structural development in the fruited vines (Fig. 1). In the absence of fruit, the vines stored the available photoassimilate in the roots as starch, and as implied by the gain in root structural biomass, also used carbohydrates toward root development. When there was no more fruit sugar accumulation, the fruited vines also stored starch. The reduced demand from the fruit therefore caused surplus carbohydrates to be stored as starch, predominantly in the roots. The absence of fruit as a carbohydrate sink induced the earlier storage of starch reserves in the roots, trunks, and shoots. Although the reduction in TNC content during rapid fruit sugar accumulation was only observed in the roots, the TNC content in the leaves, shoots, and trunks only accumulated once fruit sugar accumulation slowed.

Root TNC depletion in the fruited vines was caused by starch reduction, but coincided with increased total sugar concentrations in these roots during the maximum rates of fruit sugar accumulation. This suggests that starch was hydrolyzed, resulting in the root sugar accumulation (Regier et al., 2009). The root TNC depletion during the phase of rapid berry sugar accumulation resulted from TNC remobilization and/or root respiration. Candolfi-Vasconcelos et al. (1994) illustrated through ${ }^{14} \mathrm{C}$ that perennial $\mathrm{TNC}$ reserves are directed toward the sugar-accumulating berries when a $\mathrm{C}$ source limitation was induced by grapevine defoliation.

The water constraints of the present study restricted midday leaf $\mathrm{P}_{\mathrm{n}}$, with values comparable to field-grown grapevines subjected to severe water constraints (Medrano et al., 2003). Restricted leaf-level $\mathrm{P}_{\mathrm{n}}$ may limit canopy photoassimilation 
Arginine
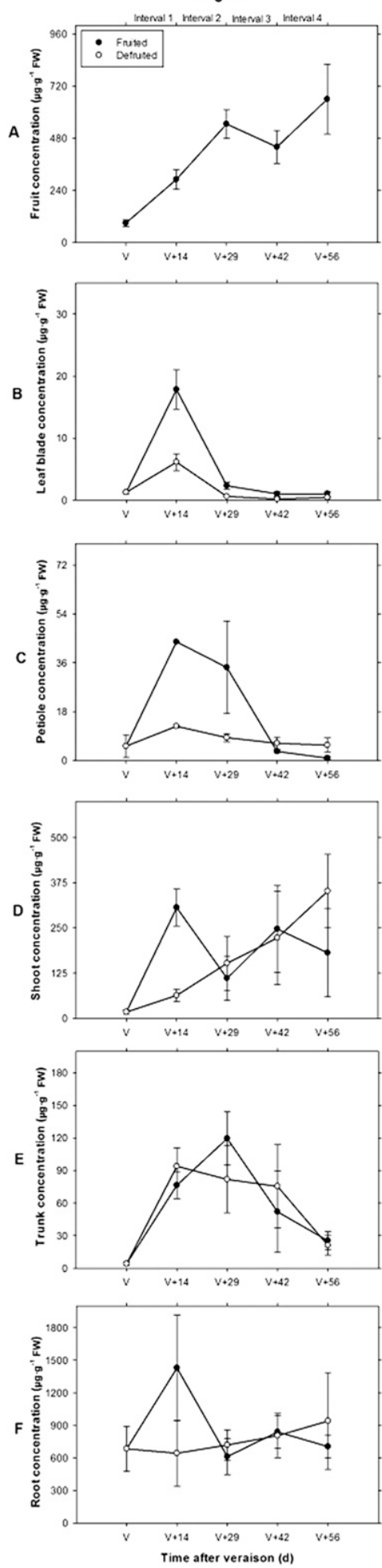

Glutamic acid
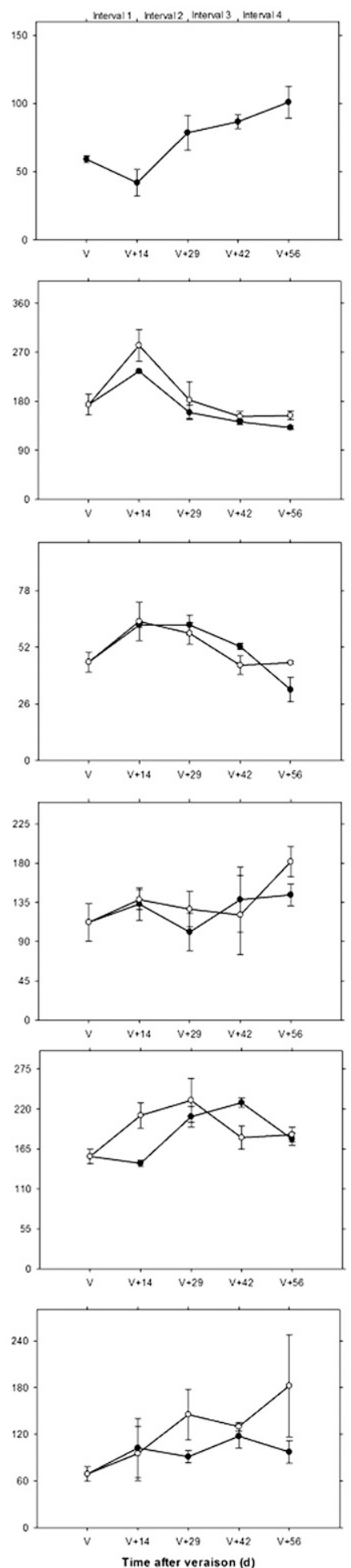

Glutamine
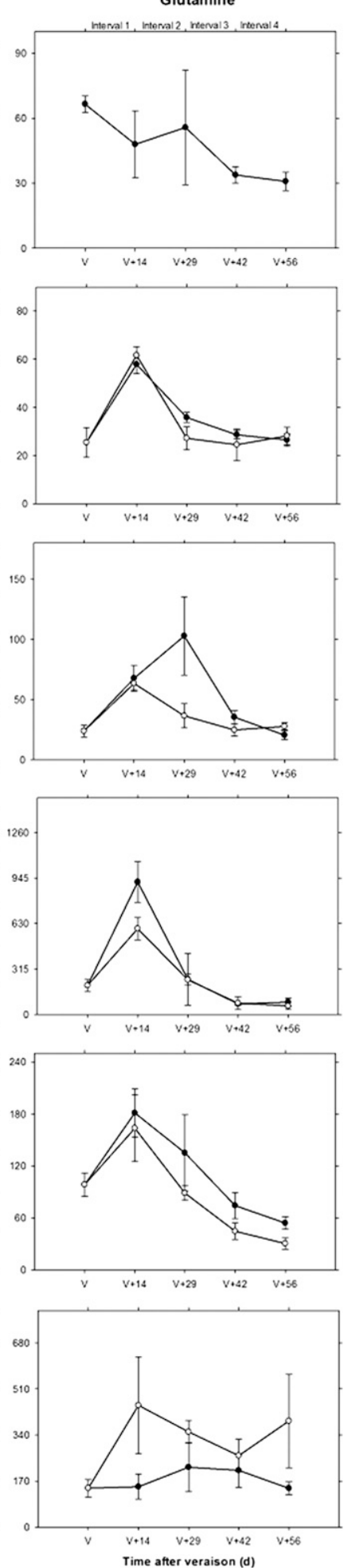

Proline
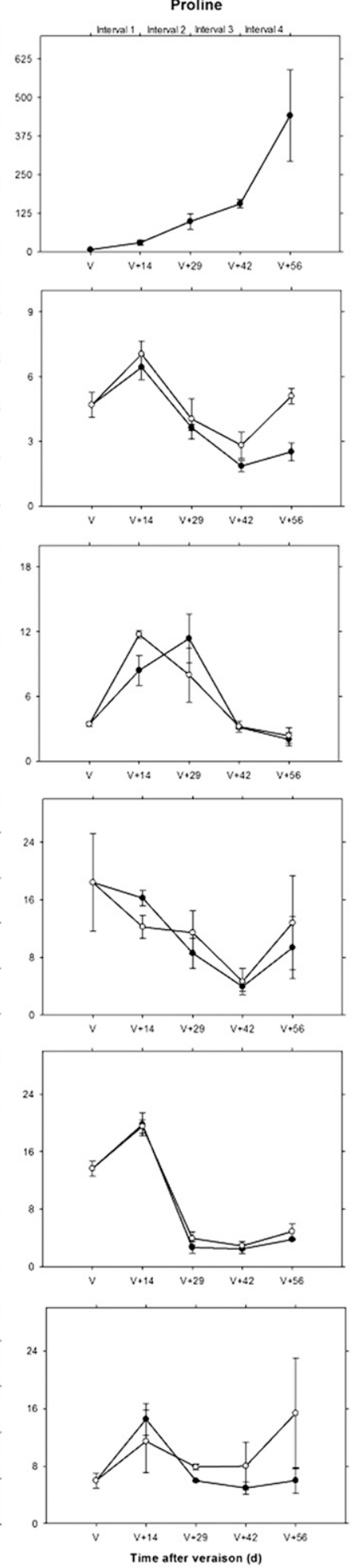

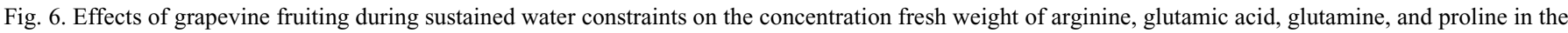
(A) fruit, (B) leaf blades, (C) petioles, (D) shoots, (E) trunks, and (F) roots. Time after veraison (d) refers to the different destructive harvest dates [V (veraison), $\mathrm{V}+14(14 \mathrm{~d}$ after $\mathrm{V}), \mathrm{V}+29(29 \mathrm{~d}$ after $\mathrm{V}), \mathrm{V}+42(42 \mathrm{~d}$ after $\mathrm{V})$, and $\mathrm{V}+56(56 \mathrm{~d}$ after $\mathrm{V})]$. The fruited treatment consisted of vines with their fruit intact between $\mathrm{V}$ and $\mathrm{V}+56$, whereas the defruited treatment consisted of vines without fruit during the same period $[\mathrm{mean} \pm \mathrm{SE}(\mathrm{n}=3)]$.

enough to induce a $\mathrm{C}$ deficiency during a period of intense fruit $\mathrm{C}$ demand. When a plant sugar deficiency occurs, gene expression related to TNC remobilization, and its exportation from source tissues is upregulated (Eveland and Jackson,
2012). As the demand from the sugar-accumulating berries in the present study was apparently greater than could be met by current photosynthesis, the abundant root starch reserves likely provided an alternative carbohydrate source. The roots 
had the highest TNC concentration, possibly explaining why significant starch depletion during rapid fruit sugar accumulation was only observed in the roots. In fact, root TNC is usually more affected by abiotic constraints and grapevine seasonal development, than the TNC in other vine parts (Holzapfel et al., 2010). As mentioned, respiration losses may also partly account for the root starch depletion during rapid fruit sugar accumulation. However, the root respiration rates of fruited pot-grown grapevines have been found to be less than defruited vines during berry maturation (Morinaga et al., 2003). Furthermore, water constraints may reduce respiration in comparison with well-watered potted vines (Escalona et al., 2012). Therefore, although root respiration may account for some of the depleted root TNC during rapid berry sugar accumulation, it also remains probable that the roots served as an alternative TNC source. Future studies may include measuring root respiration rates to quantify the related $\mathrm{C}$ expense.

The concentration of root total sugars initially decreased at the start of berry sugar accumulation. The root sugar concentration reduction, caused by sucrose depletion, suggests that existing free sugars were initially translocated out of the root system. In the subsequent sampling root sugar concentration increased resulting from the apparent starch hydrolysis (Fig. 2). The breakdown of starch through enzymatic degradation, yields C-containing intermediates such as glucans, which is subsequently restructured as sugars (Smith et al., 2005). It was during the period of maximum fruit sugar accumulation, when the root sugar concentration also rapidly increased. Sugars are osmotically active, and facilitate source-to-sink $\mathrm{C}$ translocation via the pressure flow of the phloem. Through ${ }^{14} \mathrm{C}$ labeling, Yang et al. (2002) observed rice (Oryza sativa) stem TNC reserves to be remobilized to the grains during grain filling, when these plants were subjected to water constraints. Furthermore, they described starch remobilization to coincide with stem sucrose accumulation, which was suggested to sustain the $\mathrm{C}$ flux to the grains when leaf photoassimilation was restricted. Therefore, the biosynthesis of root sugars resulting from the starch hydrolysis in the present study, suggests that these sugars became available for translocation to the ripening berries under conditions of limited $\mathrm{C}$ availability. Concurrent with the slowdown of berry sugar loading, root sugar accumulation stopped, and total root sugar concentration then reduced when berry sugar accumulation ceased. The lack of a change in the total sugar concentrations in the roots of the defruited vines is further evidence that the rate of berry sugar accumulation impacted on the root sugar abundance.

The root sucrose depletion during Interval 1 suggests that TNC translocation from the roots mainly took place through sucrose export. Grapevines, like most other plants, transport carbohydrates as sucrose (Ruan et al., 2010). The rapid root sucrose accumulation during peak berry sugar accumulation suggests that sucrose synthesis resulted from substrates provided by starch hydrolysis (Smith et al., 2005). This sucrose accumulation could create a concentration gradient between the root tissues and upper vine parts, as the berry sugar demand outweighed canopy photoassimilation, driving sucrose availability for phloem translocation to the berries, where it is hydrolyzed into glucose and fructose (Davies and Robinson, 1996). In the roots of the defruited vines, the gradual sucrose decline coincided with increased hexoses, suggesting sucrose cleavage. Furthermore, an increase in root structural biomass was observed in these vines, in agreement with Wang et al. (2010), who concluded that root hexose accumulation contributes to root growth. In fact, the accumulation of glucose and fructose in growing plant organs supports the generation of an osmotic gradient to regulate cell expansion, especially, during abiotic stresses, such as drought (Roitsch and González, 2004). As significant root sucrose was presumably exported during rapid berry sugar accumulation, it is further possible that the hexose accumulation in the roots of the fruited vines occurred to maintain cell osmotic potential (Sturm, 1999).

Similar to vine TNC, defruiting also induced higher reserve $\mathrm{N}$ accumulation, although the abundance of fruit $\mathrm{N}$ was much lower than that of its sugar. Leaves exhibited the highest $\mathrm{N}$ content at veraison, and also the only significant postveraison $\mathrm{N}$ depletion. The trend in leaf $\mathrm{N}$ reduction during Interval 1 and the significant leaf $\mathrm{N}$ depletion by $\mathrm{V}+42$ coincided with periods of fruit $\mathrm{N}$ accumulation, suggesting that leaf $\mathrm{N}$ redistribution took place toward the fruit (Verdenal et al., 2016). The accumulation of root $\mathrm{N}$ in the defruited vines suggests, in agreement with Morinaga et al. (2003), that the roots were an alternative $\mathrm{N}$ sink due to fruit absence. The lack of root $\mathrm{N}$ depletion indicates that the roots could not be considered a considerable $\mathrm{N}$ source. Root, shoot, and leaf $\mathrm{N}$ mobilization is thought to take place toward the bunches during berry maturation (Conradie, 1991). However, the water constraints of the present study likely inhibited root $\mathrm{N}$ reserve mobilization, as preharvest water constraints are thought to promote $\mathrm{N}$ allocation toward the roots (Holzapfel et al., 2015). The reason for the lack of root $\mathrm{N}$ translocation under water constraint during fruit maturation, while root TNC utilization was apparently not limited, needs further exploration.

One possibility for the differing TNC and $\mathrm{N}$ mobilization responses is that the fruit was not a strong enough $\mathrm{N}$ sink to cause a substantial root $\mathrm{N}$ loss. Furthermore, the leaves were the largest $\mathrm{N}$ source, and with almost three times more leaf than root $\mathrm{N}$ available at veraison, may have been sufficient to meet the fruit demand. Water constraints, as well as reducing the flow of water to the shoot, can induce a loss of xylem transport functioning in grapevines, by restricting xylem hydraulic conductivity (Lovisolo and Schubert, 1998). As N translocation from the roots during the period of berry maturation can take place through both the xylem and phloem (Roubelakis-Angelakis and Kliewer, 1992), the question is raised whether root $\mathrm{N}$ mobilization could have been limited due to a potential water constraint induced restricted xylem functioning, an aspect that requires further investigation. Nevertheless, despite the suggested leaf $\mathrm{N}$ contribution toward fruit $\mathrm{N}$, and although $\mathrm{N}$ fertilization was ceased 1 month before the experiment, the fruited vines seemingly absorbed $\mathrm{N}$ from the soil during the first two intervals. Grapevine soil $\mathrm{N}$ absorption is not unusual during the period soon after the start of veraison (Löhnertz, 1991). This newly absorbed $\mathrm{N}$ did not significantly affect to the total vine $\mathrm{N}$ content, but potentially contributed, together with the exported leaf $\mathrm{N}$, toward fruit $\mathrm{N}$. With the absence of fruit, the implied soil $\mathrm{N}$ uptake likely contributed to root $\mathrm{N}$ accumulation.

The elevated concentrations of amino $\mathrm{N}$ in the petioles and shoots of the fruited grapevines within Intervals 1 and 2, are possibly related to $\mathrm{N}$ translocation from the vegetative tissues toward the fruit (Conradie, 1991). Elevated petiole and shoot 
glutamine concentrations in the fruited vines were major contributors toward these amino $\mathrm{N}$ increases, and coincided (during Interval 1) with rapid fruit $\mathrm{N}$ accumulation. Glutamine is a known $\mathrm{N}$ transporter from source to sink organs in plants (Coruzzi and Last, 2000). On the other hand, the highest overall amino $\mathrm{N}$ concentrations were found in the roots of both treatments, present as arginine. Arginine is the major $\mathrm{N}$ storage compound in grapevines (Xia and Cheng, 2004), and most of the amino $\mathrm{N}$ in the perennial structures of both treatments was therefore likely related to $\mathrm{N}$ storage.

In summary, this study was performed to understand the relationship, during sustained postveraison water constraints, between the distributions of TNC and N, and the respective accumulation of sugar and $\mathrm{N}$ in the fruit. Fruiting inhibited root structural development, whereas defruiting at veraison prompted continuous root growth. During the period of rapid fruit sugar accumulation, root TNC remobilization occurred, where starch depleted, and sugars accumulated. The results suggest that root sucrose accumulation created a concentration gradient to drive sucrose transport toward the fruit. In the absence of fruit, starch accumulated, and the sucrose-to-hexose ratio decreased, indicating a potential role for hexoses as important osmotic regulators by promoting a gradient to attract water into expanding root cells. Leaf $\mathrm{N}$ depletion in the fruited vines coincided with fruit $\mathrm{N}$ accumulation, suggesting the leaves to be an important $\mathrm{N}$ source. In the absence of fruit, the roots became an alternative $\mathrm{N}$ sink. Amino $\mathrm{N}$ accumulation in the leaf petioles and shoots, largely attributed to glutamine accumulation, peaked during the first half of the experiment in the fruited vines, suggesting a role in $\mathrm{N}$ transport from the vegetative tissues toward the fruit.

Therefore, during sustained water constraints, TNC can be sourced from the roots during the rapid berry sugar accumulation phase. This has repercussions on starch storage, and may affect the vegetative and reproductive development of grapevines the following season if starch reserve replenishment is unsatisfactory. On the other hand, leaf $\mathrm{N}$ translocation can support berry $\mathrm{N}$ accumulation during sustained water constraints, causing reduced root $\mathrm{N}$ accumulation. This too could have repercussions on spring growth the following season, especially if postharvest root $\mathrm{N}$ replenishment is insufficient.

\section{Literature Cited}

Araujo, F., L.E. Williams, and M.A. Matthews. 1995. A comparative study of young 'Thompson Seedless' grapevines (Vitis vinifera L.) under drip and furrow irrigation. II. Growth, water use efficiency and nitrogen partitioning. Sci. Hort. 60:251-265.

Berg, J.M., J.L. Tymoczko, and L. Stryer. 2002. Amino acids are made from intermediates of the citric acid cycle and other major pathways, p. 670-681. In: S. Moran, M. Santee, S. DiVittorio, G.L. Hadler, P. Zimmerman, and V. Wong (eds.). Biochemisty. 5th ed. W.H. Freeman, New York, NY.

Berman, M.E. and T.M. DeJong. 1996. Water stress and crop load effects on fruit fresh and dry weights in peach (Prunus persica). Tree Physiol. 16:859-864.

Candolfi-Vasconcelos, M.C., M.P. Candolfi, and W. Koblet. 1994. Retranslocation of carbon reserves from the woody storage tissues into the fruit as a response to defoliation stress during the ripening period in Vitis vinifera L. Planta 192:567-573.

Castellví, F., P.J. Perez, J.M. Villar, and J.I. Rosell. 1996. Analysis of methods for estimating vapor pressure deficits and relative humidity. Agr. For. Meteorol. 82:29-45.
Cheng, L., G. Xia, and T. Bates. 2004. Growth and fruiting of young 'Concord' grapevines in relation to reserve nitrogen and carbohydrates. J. Amer. Soc. Hort. Sci. 129:660-666.

Choné, X., C. Van Leeuwen, D. Dubourdieu, and J.P. Gaudillère. 2001. Stem water potential is a sensitive indicator of grapevine water status. Ann. Bot. (Lond.) 87:477-483.

Conradie, W. 1991. Distribution and translocation of nitrogen absorbed during early summer by two-year-old grapevines grown in sand culture. Amer. J. Enol. Viticult. 42:180-190.

Coruzzi, G. and R. Last. 2000. Amino acids, p. 358-411. In: B. Buchanan, W. Gruissem, and R. Jones (eds.). Biochemistry and molecular biology of plants. Amer. Soc. Plant Physiol., Rockville, MD.

Davies, C. and S.P. Robinson. 1996. Sugar accumulation in grape berries (cloning of two putative vacuolar invertase cDNAs and their expression in grapevine tissues). Plant Physiol. 111:275-283.

Downton, W., W. Grant, and B. Loveys. 1987. Diurnal changes in the photosynthesis of field-grown grape vines. New Phytol. 105:71-80. Escalona, J.M., M. Tomas, H. Martolrell, H. Medrano, M. RibasCarbo, and J. Flexas. 2012. Carbon balance in grapevines under different soil water supply: Importance of whole plant respiration. Austral. J. Grape Wine Res. 18:308-318.

Eveland, A.L. and D.P. Jackson. 2012. Sugars, signalling, and plant development. J. Expt. Bot. 63:3367-3377.

Greer, D.H. 2015. Temperature-dependent responses of the photosynthetic and chlorophyll fluorescence attributes of apple (Malus domestica) leaves during a sustained high temperature event. Plant Physiol. Biochem. 97:139-146.

Hare, P.D. and W.A. Cress. 1997. Metabolic implications of stressinduced proline accumulation in plants. Plant Growth Regulat. 21:79-102.

Haynes, P.A., D. Sheumack, L.G. Greig, J. Kibby, and J.W. Redmond. 1991. Applications of automated amino acid analysis using 9fluorenylmethyl chloroformate. J. Chromatography 588:107-114.

Holzapfel, B.P., J.P. Smith, S.K. Field, and W.J. Hardie. 2010. Dynamics of carbohydrate reserves in cultivated grapevines. Hort. Rev. 37:143-211.

Holzapfel, B.P. and M.T. Treeby. 2007. Effects of timing and rate of N supply on leaf nitrogen status, grape yield and juice composition from Shiraz grapevines grafted to one of three different rootstocks. Austral. J. Grape Wine Res. 13:14-22.

Holzapfel, B.P., J. Watt, J.P. Smith, K. Suklje, and S.Y. Rogiers. 2015. Timing of $\mathrm{N}$ application and water constraints on $\mathrm{N}$ accumulation and juice amino $\mathrm{N}$ concentration in Chardonnay grapevines. Vitis 54:203-211.

Löhnertz, O. 1991. Soil nitrogen and the uptake of nitrogen in grapevines, p. 1-11. In: J.M. Rantz (ed.). Intl. Symp. Nitrogen in Grapes and Wine. Amer. Soc. Enol. Viticult., Seattle, WA.

Lovisolo, C. and A. Schubert. 1998. Effects of water stress on vessel size and xylem hydraulic conductivity in Vitis vinifera L. J. Expt. Bot. 49:693-700.

Medrano, H., J.E. Escalona, J. Cifre, J. Bota, and J. Flexas. 2003. A tenyear study on the physiology of two Spanish grapevine cultivars under field conditions: Effects of water availability from leaf photosynthesis to grape yield and quality. Funct. Plant Biol. 30:607-619.

Morinaga, K., S. Imai, H. Yakushiji, and Y. Koshita. 2003. Effects of fruit load on partitioning of ${ }^{15} \mathrm{~N}$ and ${ }^{13} \mathrm{C}$, respiration, and growth of grapevine roots at different fruit stages. Sci. Hort. 97:239-253.

Reed, A.B., C.J. O'Conner, L.D. Mwelton, and B.G. Smith. 2004. Determination of sugar composition in grapevine rootsotck cuttings used for propagation. Amer. J. Enol. Viticult. 55:181-186.

Regier, N., S. Streb, C. Cocozza, M. Schaub, P. Cherubini, S.C. Zeeman, and B. Frey. 2009. Drought tolerance of two black poplar (Populus nigra L.) clones: Contribution of carbohydrates and oxidative stress defence. Plant Cell Environ. 32:1724-1736.

Rodriguez-Lovelle, B. and J.-P. Gaudillere. 2002. Carbon and nitrogen partitioning in either fruiting or non-fruiting grapevines: Effects of nitrogen limitation before and after veraison. Austral. J. Grape Wine Res. 8:86-94. 
Roitsch, T. and M.C. González. 2004. Function and regulation of plant invertases: Sweet sensations. Trends Plant Sci. 9:606-613.

Roubelakis-Angelakis, K.A. and W.M. Kliewer. 1992. Nitrogen metabolism in grapevine. Hort. Rev. 14:407-452.

Ruan, Y.L., Y. Jin, Y.J. Yang, G.J. Li, and J.S. Boyer. 2010. Sugar input, metabolism, and signaling mediated by invertase: Roles in development, yield potential, and response to drought and heat. Mol. Plant 3:942-955.

Smith, A.M., S.C. Zeeman, and S.M. Smith. 2005. Starch degradation. Annu. Rev. Plant Biol. 56:73-98.

Smith, J.P. and B.P. Holzapfel. 2009. Cumulative responses of Semillon grapevines to late season perturbation of carbohydrate reserve status. Amer. J. Enol. Viticult. 60:461-470.

Sturm, A. 1999. Invertases. Primary structures, functions, and roles in plant development and sucrose partitioning. Plant Physiol. 121:1-8.

Van Leeuwen, C., O. Tregoat, X. Choné, B. Bois, D. Pernet, and J.-P. Gaudillère. 2009. Vine water status is a key factor in grape ripening and vintage quality for red Bordeaux wine. How can it be assessed for vineyard management purposes. J. Intl. Sci. Vigne Vin 43: 121-134.

Verdenal, T., J.E. Spangenberg, V. Zufferey, F. Lorenzini, A. Dienes, K. Gindro, J.-L. Spring, and O. Viret. 2016. Leaf-to-fruit ratio affects the impact of foliar-applied nitrogen on $\mathrm{N}$ accumulation in the grape must. J. Intl. Sci. Vigne Vin 50:23-33.

Verma, D.P.S., C. Zhang, and B. Singh. 1999. Regulation of proline and arginine biosynthesis in plants, p. 249-265. In: B.K. Singh (ed.). Plant amino acids: Biochemistry and biotechnology. Marcel Dekker, New York, NY.

Wang, L., X.R. Li, H. Lian, D.A. Ni, Y.K. He, X.Y. Chen, and Y.L. Ruan. 2010. Evidence that high activity of vacuolar invertase is required for cotton fiber and Arabidopsis root elongation through osmotic dependent and independent pathways, respectively. Plant Physiol. 154:744-756.

Xia, G. and L. Cheng. 2004. Foliar urea application in the fall affects both nitrogen and carbon storage in young 'Concord' grapevines grown under a wide range of nitrogen supply. J. Amer. Soc. Hort. Sci. 129:653-659.

Yang, J., J. Zhang, Z. Wang, Q. Zhu, and L. Liu. 2002. Abscisic acid and cytokinins in the root exudates and leaves and their relationship to senescence and remobilization of carbon reserves in rice subjected to water stress during grain filling. Planta 215:645-652.

Zapata, C., E. Deléens, S. Chaillou, and C. Magné. 2004. Mobilisation and distribution of starch and total $\mathrm{N}$ in two grapevine cultivars differing in their susceptibility to shedding. Funct. Plant Biol. 31:1127-1135. 